\title{
Bone disease in patients with chronic kidney disease under conservative management
}

\author{
Nephrology Division, Hospital Universitário Pedro Ernesto, Universidade \\ do Estado do Rio de Janeiro, Rio de Janeiro, Brazil
}

\section{INTRDDUCTION}

Chronic kidney disease today is becoming one of the most important public health problems. In Brazil, there are now approximately 60,000 patients undergoing dialytic treatment and it is thought that more than $1,000,000$ people have some level of renal dysfunction. This syndrome leads to many long-term complications in different organs (anemia, bone disease, cardiovascular damage and malnutrition) and maintenance of adequate treatment for the population with this set of illnesses imposes a large economic burden. For example, new drugs like the phosphorus binder sevelamer and calcimimetics agents are being used in complicated cases of hyperphosphatemia, in patients under dialysis treatment, but they are expensive. This shows the importance of early diagnosis and treatment, so as to avoid such complications.

Renal osteodystrophy, a common feature among patients with chronic kidney disease, has been widely studied in populations submitted to renal function substitution treatment. When the glomerular filtration rate falls to half of its normal value, approximately $50 \%$ of such patients are already presenting histological bone lesions. ${ }^{1}$ There is a lack of data for characterizing the prevalence of renal osteodystrophy among the pre-dialysis population. There are reports suggesting a high prevalence of low-turnover disease, ${ }^{2,3}$ and mixed lesion. ${ }^{4}$ However, high-turnover disease seems to be the main expression of secondary hyperparathyroidism. ${ }^{1,5}$ Bone biopsy is still the gold-standard for the diagnosis of renal osteodystrophy, ${ }^{1,6,7}$ although it is infrequently used at the pre-dialysis phase, when patients are followed by means of serum biochemistry parameters. Among the methods utilized for evaluating parathyroid hormone (PTH), assaying of intact PTH (iPTH) is considered to be the most specific, and this forms a noninvasive method for diagnosing hyperparathyroidism. ${ }^{3}$ Besides iPTH, other markers have been proposed. ${ }^{8}$ Bone alkaline phosphatase is a glycoprotein anchored in the cellular membrane of the osteoblasts that is not filtered by the kidneys or dialysis, and it has been suggested that it would be the best marker for bone disease in chronic kidney disease. ${ }^{9}$ Studies analyzing the bone histology of patients on dialysis have shown good correlation between this marker and osteoblastic activity, and have suggested that it is superior to iPTH and alkaline phosphatase. ${ }^{10}$ This issue has not been well studied in populations under conservative treatment.

The objective of the present study was thus to evaluate the biochemical and hormonal profile related to bone disease, among patients with chronic kidney disease under conservative treatment.

METHODS

The study group consisted of 131 outpatients who were being followed up by the $\mathrm{Ne}$ phrology Division of Hospital Pedro Ernesto, Universidade do Estado do Rio de Janeiro. All patients signed an informed consent statement regarding their participation in the study, which had previously been approved by the institution's review board. All patients were followed up by nephrologists and nutritionists. The patients' creatinine clearance ranged from 10 to $60 \mathrm{ml} / \mathrm{min} / 1.73 \mathrm{~m}^{2}$. Protein intake had been prescribed, ranging from 0.8 to 1 $\mathrm{g} / \mathrm{kg} /$ day, and all patients were taking calcium carbonate supplementation. Patients were excluded if they were less than 18 years of age, had had less than one year of follow-up, had parathyroid disease, or were using vitamin D intake, dialysis procedures, hormonal replacement therapy, glucocorticoids, phosphorus binder with aluminum, or drugs that directly interfere in bone metabolism.

\section{ABSTRACT}

CONTEXT AND OBJECTIVE: Few studies have focused on bone disease in patients with chronic kidney disease under conservative treatment. The objective was to evaluate bone disease in patients with chronic kidney disease.

DESIGN AND SETTING: Case series, at the Nephrology Division, Hospital Universitário Pedro Ernesto.

METHODS: 131 patients with creatinine clearance from 10 to $60 \mathrm{ml} / \mathrm{min} / 1.73 \mathrm{~m}^{2}$ were followed up for at least one year. Serum creatinine, albumin, calcium, phosphorus, alkaline phosphatase, total $\mathrm{CO}_{2}\left(+\mathrm{CO}_{2}\right)$, intact parathyroid hormone (iPTH), and alkaline phosphatase were measured. Creatinine clearance was calculated from 24-hour urine creatinine measurements and protein ingestion estimates from urea assays.

RESULTS: Patients presenting creatinine clearance $<30 \mathrm{ml} / \mathrm{min} / 1.73 \mathrm{~m}^{2}$ had higher iPTH values, but normal serum levels for calcium, phosphorus, alkaline phosphatase and $+\mathrm{CO}_{2}$. Patients presenting $\mathrm{PPTH}$ values of twice the normal upper limit $(144 \mathrm{pg} / \mathrm{ml})$ showed lower $\mathrm{CCO}_{2}$ values. Bone alkaline phosphatase was evaluated in 37 patients with creatinine clearance $<30 \mathrm{ml} / \mathrm{min} / 1.73 \mathrm{~m}^{2}$, showing correlation with alkaline phosphatase but not with parathyroid hormone. Bone biopsy on nine patients with creatinine clearance < $30 \mathrm{ml} / \mathrm{min} / 1.73 \mathrm{~m}^{2}$ and $\mathrm{PTH}>144 \mathrm{pg} / \mathrm{ml}$ showed osteitis fibrosa (4), mild lesion (4) and high turnover (1).

CONCLUSION: The present data suggest the importance of early control for iPTH and metabolic acidosis, among patients under conservative management for chronic kidney disease, in order to prevent complications related to bone disease.

KEY WORDS: Renal osteodystrophy. Kidney diseases. Chronic kidney failure. Renal dialysis. Bone resorption. 
Evaluations of serum creatinine, albumin, calcium, phosphorus, total $\mathrm{CO}_{2}\left(\mathrm{tCO}_{2}\right)$ and alkaline phosphatase were performed. Urea and creatinine were measured from 24-hour urine. The protein ingestion estimate was calculated using the equation: $0.466)+(0.031 \mathrm{x}$ body weight $)] \times 6.25 /$ body weight ( $\mathrm{g}$ of protein $/ \mathrm{kg} /$ day).

Intact PTH was evaluated by immunochemiluminometric assay (reference values: $12-72 \mathrm{pg} / \mathrm{ml}$ ). Bone alkaline phosphatase was evaluated in 37 patients with creatinine clearance $<30 \mathrm{ml} / \mathrm{min} / 1.73 \mathrm{~m}^{2}$, by the immunoenzymatic method (reference values: $14.8-65.2 \mathrm{U} / \mathrm{l})$.

Nine patients with creatinine clearance $<30 \mathrm{ml} / \mathrm{min} / 1.73 \mathrm{~m}^{2}$ and iPTH of twice the highest normal value were submitted to bone biopsy. Patients were given two courses of tetracycline separated by an interval of 12 days. The biopsy was performed four days after the last dose of tetracycline. The bone samples were fixed in $70 \%$ ethanol and dehydrated by sequential changes in ascending concentrations of ethanol and xylene and then embedded in methyl methacrylate. For histological analysis, undecalcified sections $(5 \mu \mathrm{m})$ of cortical and trabecular bone were stained by the Goldner method and by aurintricarboxylic acid for detection of aluminum. Bone remodeling and turnover were investigated on $10-\mu \mathrm{m}$ unstained sections under fluorescent light.

The histological classification for the skeletal lesions of renal osteodystrophy that was used in this study was as follows: osteitis fibrosa: increased remodeling and bone marrow fibrosis; mild renal osteodystrophy lesion: slightly increased bone remodeling and no fibrosis; osteomalacia: increased osteoid volume and surface, defective mineralization; adynamic
Estimated protein ingestion $=[($ urinary urea $\mathrm{x}$

bone disease: hypocellular bone surfaces, no remodeling; mixed renal osteodystrophy: features of both osteitis fibrosa and osteomalacia. ${ }^{11}$

\section{BTATIBTICAL ANALYBIB}

Results are presented as mean \pm standard deviation for quantitative variables with symmetrical distribution, and median and range for the variables with asymmetric distribution. Comparisons between two groups were performed using the $t$ test for parametric data, Mann-Whitney test for non-parametric data (iPTH and alkaline phosphatase) and chisquared test for qualitative variables. Linear correlation analysis was done by means of the Pearson $r$ or Spearman $r$ coefficient, in accordance, respectively, with symmetric or asymmetric distribution of the variables.

RESULTS

The mean age of the studied population was $61 \pm 14$ years and $67 \%$ were white, $13 \%$ black and 20\% non-white and non-black. The gender distribution was $54 \%$ men and $46 \%$ women. The etiologies of the chronic kidney disease were hypertension $39 \%$, diabetes mellitus $23 \%$, unknown $15 \%$, polycystic kidney disease $9 \%$, primary glomerulopathy $6 \%$, chronic pyelonephritis 3\% and others 5\%.

The biochemical data were analyzed in two stages (Figure 1). In the first stage (Table 1) patients were divided into two groups according to their creatinine clearance: $<30$ $\mathrm{ml} / \mathrm{min} / 1.73 \mathrm{~m}^{2}(\mathrm{n}=87$, group I) and $>30$ $\mathrm{ml} / \mathrm{min} / 1.73 \mathrm{~m}^{2}$ ( $\mathrm{n}=44$, group II). There were no differences in age, gender, estimated protein ingestion $(0.8 \pm 0.3$ vs. $0.9 \pm 0.3$ $\mathrm{g} / \mathrm{kg} /$ day $)$ and albumin $(4.5 \pm 0.4$ vs. $4.4 \pm$ $0.7 \mathrm{~g} / \mathrm{dl}$ ) between the groups. Group I had a lower value for calcium, and higher values for alkaline phosphatase and iPTH, thus suggest-

Figure 1. Protocol for 131 patients followed up in an outpatient nephrology service in Rio de Janeiro, Brazil.

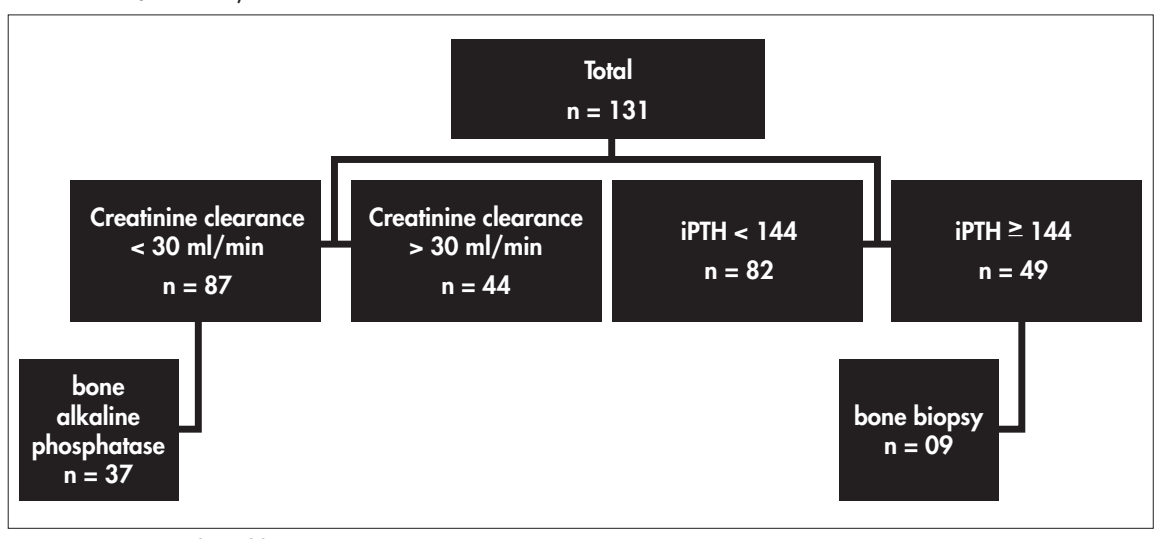

iPTH = intact parathyroid hormone. ing that these patients' bone tissue was more severely compromised. Phosphorus and total $\mathrm{CO}_{2}$ values were similar in the two groups. It is important to point out that all the parameters analyzed were within their normal ranges.

In the second stage, patients were divided according to their iPTH levels (median) as follows: those with values of up to twice the upper limit for iPTH (group I: iPTH $<144 \mathrm{pg} / \mathrm{ml} ; \mathrm{n}=82$ ) and those above this level (group II: iPTH > $144 \mathrm{pg} / \mathrm{ml} ; \mathrm{n}=49$ ). There was no difference in gender, age, serum albumin $(4.5 \pm 0.6$ vs. $4.4 \pm 0.4 \mathrm{~g} / \mathrm{dl})$ or estimated protein ingestion $(0.8 \pm 0.3 \mathrm{~g} / \mathrm{kg} /$ day, for both) between the groups. Table 2 shows that alkaline phosphatase values were normal, and $\mathrm{PTH}$ was 3-4 times higher in group II than in group I. The group with higher iPTH levels had lower calcium and higher phosphorus values, and also lower total $\mathrm{CO}_{2}$ value. In 37 patients with mean age $61 \pm 12$ years (kidney glomerular filtration rate, GFR, of < $30 \mathrm{ml} / \mathrm{min} / 1.73 \mathrm{~m}^{2}$ ), bone alkaline phosphatase serum levels were evaluated. This group showed normal mean serum levels for albumin $(4.4 \pm 0.5 \mathrm{~g} / \mathrm{l})$, calcium $(9.3 \pm 0.6 \mathrm{mg} / \mathrm{dl})$, phosphorus $(4.1 \pm 0.6 \mathrm{mg} / \mathrm{dl})$ and estimated protein ingestion (EPI) $(0.8 \pm 0.3 \mathrm{~g} / \mathrm{kg} / \mathrm{day})$. Mean total $\mathrm{CO}_{2}$ was $21.9 \pm 3.4 \mathrm{mEq} / \mathrm{l}$, thus indicating metabolic acidosis. The median for iPTH was 137 pg/ml (range: 30 - 752 pg/ml). The median for alkaline phosphatase was 94 U/l (range: $52-673 \mathrm{U} / \mathrm{I}$ ), while the median for bone alkaline phosphatase was $25.8 \mathrm{U} / \mathrm{l}$ (range: $8.3-50 \mathrm{U} / \mathrm{l}$ ). A comparison between bone alkaline phosphatase and iPTH showed Spearman $r=0.18$. When bone alkaline phosphatase was compared to alkaline phosphatase, a good correlation was observed (Spearman $r$ $=0.69, \mathrm{p}<0.001$ ).

Nine patients with creatinine clearance $<$ $30 \mathrm{ml} / \mathrm{min} / 1.73 \mathrm{~m}^{2}$ were submitted to bone biopsy, which showed median iPTH of 263 $\mathrm{pg} / \mathrm{ml}$ (range: $151-767 \mathrm{pg} / \mathrm{ml}$ ), and median bone alkaline phosphatase median of $23.1 \mathrm{U} / 1$ (range: 8.3-50). These values did not present correlation between them. The median alkaline phosphatase of $103 \mathrm{U} / \mathrm{l}$ (range: $66-180$ $\mathrm{U} / \mathrm{l})$, albumin $(4.3 \pm 0.5 \mathrm{~g} / \mathrm{l})$, calcium $(9.4$ $\pm 0.7 \mathrm{mg} / \mathrm{dl})$, phosphorus $(4.6 \pm 1.2 \mathrm{mg} / \mathrm{dl})$ and EPI $(0.8 \pm 0.3 \mathrm{~g} / \mathrm{kg} /$ day $)$ were normal, although total $\mathrm{CO}_{2}$ was low $(21.9 \pm 3.4 \mathrm{mEq} /$ 1). The histological evaluation showed osteitis fibrosa $(n=4)$, mild lesion $(n=4)$ and high turnover alone $(\mathrm{n}=1)$.

DISCUSSIDN

This study evaluated outpatients with chronic kidney disease under conservative 
treatment, and showed their biochemical profiles, focusing on secondary hyperparathyroidism. Bone alkaline phosphatase was also evaluated in order to analyze its utility as a marker for renal osteodystrophy. Additionally, bone biopsies were performed to illustrate bone histology in this population. Recent data have suggested that the black population is at higher risk of developing secondary hyperparathyroidism. ${ }^{12}$ In the present study, only $13 \%$ of the population was black, and this did not influence the results. In analyzing the etiologies of chronic kidney disease we observed that arterial hypertension, diabetes and unknown causes were responsible for $78 \%$ of the cases. Some reports have suggested that diabetic patients show a lower incidence of secondary hyperparathyroidism. ${ }^{13}$ However, such evaluation was outside of the objectives of the present study.

The study population ( $\mathrm{n}=131)$ was divided according to two criteria. First, according to their creatinine clearance and, subsequently, by iPTH level. Measurements of iPTH by immunochemiluminometric assay showed high intra-assay reproducibility, which corroborates data from the literature suggesting the utility of this method. ${ }^{14}$ The present data showed that the median $\mathrm{PPTH}$ was significantly higher among patients with reduced renal function. The biochemical serum data did not show any difference in phosphorus levels, a parameter that has been implicated as an independent factor for increases in PTH. ${ }^{15}$ This was probably a consequence of the dietary control and the phosphorus binder usage by all patients in our study. The mean values for calcium and total $\mathrm{CO}_{2}$ were significantly lower among patients with reduced renal function, and their median alkaline phosphatase was higher.

Although statistically different, the absolute values for all the abovementioned parameters were within the normal range. It was demonstrated that patients with early chronic kidney disease, and even in more advanced phases, showed normal values for $\mathrm{Ca}$ and $\mathrm{P}$ despite the presence of elevated iPTH. ${ }^{15}$ In the present study, when groups were analyzed according to iPTH level, they showed similar values for albumin and estimated protein ingestion, thus suggesting good dietary control. Although the mean values for calcium and phosphorus were within the normal range, they were lower and higher, respectively, in the group with iPTH > $144 \mathrm{pg} / \mathrm{ml}$. Alkaline phosphatase was similar for the two groups, thus suggesting that it is not useful as an independent marker for hyperparathyroidism within this population. Patients showing
$\mathrm{iPTH}>144 \mathrm{pg} / \mathrm{ml}$ presented low total $\mathrm{CO}_{2}$, meaning that metabolic acidosis was the only abnormal serum parameter in patients with higher levels of iPTH. This result points to the fact that, even with good dietary control, phosphorus binder usage, and normal serum levels for calcium and phosphorus, patients may present metabolic acidosis and hyperparathyroidism.

We conclude that measurement of iPTH from the early beginnings of chronic kidney disease, and also the control of metabolic acidosis, are of great importance in this population. Metabolic acidosis, which is known to correlate with renal osteodystrophy, has been shown to favor PTH actions such as increasing osteoclastic activity and reducing vitamin D levels. Additionally, it acts within the bone to promote an efflux of cations (like calcium) to the blood. ${ }^{16}$ This efflux leads to mineral loss from bone, thereby worsening the osteodystrophy. Other studies ${ }^{17}$ have demonstrated that normalization of acidosis in chronic renal patients led to increased 1,25(OH)2D3 levels and, consequently, inhibited PTH production. These results suggest that metabolic acidosis in these patients needs to be well controlled, in order to minimize the effects of hyperparathyroidism.

There is a lack of evaluations of markers for bone disease in patients under conservative management: the majority of studies have been performed on patients under dialysis treatment. Bone alkaline phosphatase is considered to be among the non-invasive markers of bone disease. It is more sensitive and specific for renal osteodystrophy, and good correlation with iPTH has been shown. ${ }^{18}$ Two studies have analyzed bone alkaline phosphatase in chronic renal patients before they started dialysis. One of them evaluated children, ${ }^{18}$ and thus cannot be compared with results from adults. The other study, ${ }^{9}$ evaluated 28 patients with GFR $<26 \mathrm{ml} / \mathrm{min} / 1.73 \mathrm{~m}^{2}$ who were not under dietary control or phosphorus binder usage; it showed moderate correlation between bone alkaline phosphatase and iPTH. Histological evaluations were not performed on any of these subjects. A recent study ${ }^{19}$ analyzing 84 patients with creatinine clearance $<5$ $\mathrm{ml} / \mathrm{min} / 1.73 \mathrm{~m}^{2}$ showed only eight patients with hyperparathyroidism, and bone alkaline phosphatase was a good marker for detection of adynamic bone disease.

In the present study, patients with elevated iPTH levels, showed normal values for albumin, estimated protein ingestion, calcium, phosphorus and alkaline phosphatase. The only abnormality observed was a tendency towards metabolic acidosis. Although iPTH was twice its upper limit, bone alkaline phosphatase levels were normal. Comparison between iPTH and bone alkaline phosphatase showed no correlation, although good correla-

Table 1. Profile of 131 patients followed up in an outpatient nephrology service in Rio de Janeiro, Brazil, according to creatinine clearance

\begin{tabular}{lccc}
\hline & $\begin{array}{c}\text { Group I } \\
\text { Creatinine clearance } \\
\leq \mathbf{3 0 ~} \mathbf{~ m l} / \mathbf{m i n} \\
(\mathbf{n}=\mathbf{8 7})\end{array}$ & $\begin{array}{c}\text { Group II } \\
\text { Creatinine clearance } \\
>\mathbf{3 0 ~} \mathbf{m l} / \mathbf{m i n} \\
(\mathbf{n}=\mathbf{4 4})\end{array}$ & p value \\
& $9.2 \pm 0.6$ & $9.5 \pm 0.6$ & \\
\hline Calcium (mg/dl) & $4.0 \pm 0.7$ & $3.8 \pm 0.7$ & $0.024^{*}$ \\
Phosphorus (mg/dl) & $95(31-673)$ & $88(29-165)$ & $0.13^{*}$ \\
Alkaline phosphatase (U/l) & $22.2 \pm 3.9$ & $23.8 \pm 3.2$ & $0.035^{* *}$ \\
Total CO $(\mathrm{mEq} / \mathrm{l})$ & $136(1-1,435)$ & $84(5-229)$ & $0.02^{*}$ \\
iPTH $(\mathrm{pg} / \mathrm{ml})$ & $<0.001^{* *}$ \\
\hline
\end{tabular}

iPTH $=$ intact parathyroid hormone; ${ }^{*} t$ test; ${ }^{*}$ Mann-whitney test. Results are expressed as mean \pm standard deviation or, for alkaline phosphatase and iPTH, as median (range).

Table 2. Profile of 131 studied patients followed up in an outpatient nephrology service in Rio de Janeiro, Brazil, according to iPTH

\begin{tabular}{|c|c|c|c|}
\hline & $\begin{array}{c}\text { Group I } \\
\text { iPTH }<144 \mathrm{pg} / \mathrm{ml} \\
(\mathrm{n}=82)\end{array}$ & $\begin{array}{c}\text { Group II } \\
\text { iPTH } \geq 144 \mathrm{pg} / \mathrm{ml} \\
(\mathrm{n}=49)\end{array}$ & p value \\
\hline Calcium (mg/dl) & $9.5 \pm 0.6$ & $9.0 \pm 0.6$ & $<0.001^{*}$ \\
\hline Phosphorus (mg/dl) & $3.9 \pm 0.6$ & $4.1 \pm 0.7$ & $0.021^{*}$ \\
\hline Alkaline phosphatase (U/I) & $88(29-673)$ & $97(31-393)$ & 0.196 ** \\
\hline Total $\mathrm{CO}_{2}(\mathrm{mEq} / \mathrm{l})$ & $23.6 \pm 3.4$ & $21.3 \pm 3.9$ & $0.001 *$ \\
\hline iPTH (pg/ml) & $80(1-142)$ & $273(147-1,435)$ & $<0.001^{* *}$ \\
\hline
\end{tabular}

Results are expressed as mean \pm standard deviation or, for alkaline phosphatase and $\mathrm{PTH}$, as median (range). ${ }^{*}=t$ test ${ }^{* *}=$ Mann-Whitney test; iPTH = intact parathyroid hormone. 
tion between bone alkaline phosphatase and alkaline phosphatase $(r=0.69 ; \mathrm{p}<0.001)$ was observed.

Nine patients with iPTH $>144 \mathrm{pg} / \mathrm{ml}$ were submitted to bone biopsy. Histological analysis showed that all of them presented hyperparathyroidism abnormalities: even the patients with normal bone alkaline phosphatase. These data suggest that bone alkaline phosphatase lacks accuracy as a marker for high-turnover disease in this population. Moreover, at this stage of chronic kidney disease, it was no more sensitive or specific than alkaline phosphatase, which is cheaper and easier to evaluate. There are few data in the literature showing bone histological evaluations from patients with chronic kidney disease under conservative treatment. Solal et al. ${ }^{17}$ found high prevalence of osteitis fibrosa among 27 patients who were not submitted to dietary control or usage of phosphate binders. Carvalho et al., ${ }^{2}$ showed high prevalence of mixed and adynamic diseases among 23 patients without specific treatment. LafageProust et al. ${ }^{20}$ studied 16 patients under very low protein diet supplemented with keto- analogs, and found high prevalence of normal bone, followed by low-turnover disease; however, these patients showed iPTH levels of twice its normal upper limit. Baker et al. ${ }^{6}$ showed, in 16 patients submitted to bone biopsies, that calcitriol usage in low doses is safe and that it improved the hyperparathyroidism lesions. Hamdy et al. ${ }^{5}$ studied 176 patients and found high prevalence of osteitis fibrosa. They also suggested that administration of vitamin $\mathrm{D}$ to this population would be beneficial. Another study ${ }^{4}$ on 76 patients showed that mixed renal osteodystrophy and adynamic disease was more common. The heterogeneity of the results reflects the wide spectrum of iPTH levels, the diversity of the criteria used by pathologists, local factors, dietary control, usage of vitamin $\mathrm{D}$, etc. Another difficulty in comparing these studies is that creatinine clearance ranged from 60 $\mathrm{ml} / \mathrm{min} / 1.73 \mathrm{~m}^{2}$ to $5 \mathrm{ml} / \mathrm{min} / 1.73 \mathrm{~m}^{2}$, and the study populations were not followed up using specific treatment.

In the present study, the group presenting creatinine clearance from 10 to 30 $\mathrm{ml} / \mathrm{min} / 1.73 \mathrm{~m}^{2}$ and $\mathrm{iPTH}>144 \mathrm{pg} / \mathrm{ml}$ was homogenous. It was followed up by specialists and showed normal biochemical serum profiles. Even so, those submitted to bone biopsies presented abnormalities. The present results are in agreement with the suggestion by Hutchinson ${ }^{1}$ that iPTH levels should be maintained up to twice the normal upper limit for this population of chronic renal patients.

In summary, normal serum levels of calcium, phosphorus, alkaline phosphatase and bone alkaline phosphatase in chronic renal patients under conservative treatment do not imply normal iPTH. Metabolic acidosis was the only laboratory abnormality in this population, and this was associated with secondary hyperparathyroidism. Patients with iPTH of twice its normal value may present the histological lesions of hyperparathyroidism.

CINCLUSION

These data suggest the importance of early control of PTH and metabolic acidosis, in order to avoid complications related to renal bone disease.
1. Hutchison AJ, Whitehouse RW, Boulton HF, et al. Correlation of bone histology with parathyroid hormone, vitamin D3, and radiology in end-stage renal disease. Kidney Int. 1993;44(5):1071-7.

2. Carvalho AB, Lobao RR, Cuppari L, Draibe SA, Ajzen H. Does hypophosphataemia induce hypoparathyroidism in pre-dialysis patients?. Nephrol Dial Transplant. 1998;(13 Suppl 3):12-4.

3. Torres A, Lorenzo V, Hernández D, et al. Bone disease in predialysis, hemodialysis, and CAPD patients: evidence of a better bone response to PTH. Kidney Int. 1995; 47(5):1434-42.

4. Coen G, Mazzaferro S, Ballanti P, et al. Renal bone disease in 76 patients with varying degrees of predialysis chronic renal failure: a cross sectional study. Nephrol Dial Transplant. 1996;11(5):813-9.

5. Hamdy NA, Kanis JA, Beneton MN, et al. Effect of alfacalcido on natural course of renal bone disease in mild to moderate renal failure. BMJ. 1995;310(6976):358-63.

6. Baker LR, Abrams L, Roe CJ, et al. 1,25(OH)2D3 administration in moderate renal failure: a prospective double-blind trial. Kidney Int. 1989;35(2):661-9.

7. Ho LT, Sprague SM. Percutaneous bone biopsy in the diagnosis of renal osteodystrophy. Semin Nephrol. 2002;22(3):268-75.

8. Eriksen EF, Brixen K, Charles P. New markers of bone metabolism: clinical use in metabolic bone disease. Eur J Endocrinol. 1995;132(3):251-63.
9. Rix M, Andreassen H, Eskildsen P, Langdahl B, Olgaard K. Bone mineral density and biochemical markers of bone turnover in patients with predialysis chronic renal failure. Kidney Int. 1999;56(3):1084-93.

10. Ureña P, Hruby M, Ferreira A, Ang KS, de Vernejoul MC. Plasma total versus bone alkaline phosphatase as markers of bone turnover in hemodialysis patients. J Am Soc Nephrol. 1996;7(3):506-12.

11. Duarte ME, Peixoto AL, Pacheco AS, et al. The spectrum of bone disease in 200 chronic hemodialysis patients: a correlation between clinical, biochemical and histological findings. Rev Paul Med.1998;116(5):1790-7.

12. Gupta A, Kallenbach LR, Zasuwa G, Divine GW. Race is a major determinant of secondary hyperparathyroidism in uremic patients. J Am Soc Nephrol. 2000;11(2):330-4.

13. Martínez R, Saracho R, Moina I, Montenegro J, Llach F. Is there a lesser hyperparathyroidism in diabetic patient with chronic renal failure? Nephrol Dial Transplant. 1998;13(Suppl 3):9-11.

14. Brown RC, Aston JP, Weeks I, Woodhead JS. Circulating intact parathyroid hormone measured by a two-site immunochemiluminometric assay. J Clin Endocrinol Metab. 1987;65(3):407-14.

15. Malluche HH, Monier-Faugere MC. Understanding and managing hyperphosphatemia in patients with chronic renal disease. Clin Nephrol. 1999;52(5):267-77.
16. Bushinsky DA. Hydrogen Ions. In: Bushinsky DA, editor. Renal Osteodystrophy. New York: Lippincott-Raven; 1998. p.103-27.

17. Solal ME, Sebert JL, Boudailliez B, et al. Comparison of intact, midregion, and carboxy terminal assays of parathyroid hormone for the diagnosis of bone disease in hemodialyzed patients. J Clin Endocrinol Metab. 1991;73(3):516-24.

18. Jarava C, Armas JR, Salgueira M, Palma A. Bone alkaline phosphatase isoenzyme in renal osteodystrophy. Nephrol Dial Transplant. 1996;11(Suppl 3):43-6.

19. Bervoets AR, Spasovski GB, Behets GJ, et al. Useful biochemical markers for diagnosing renal osteodystrophy in predialysis end-stage renal failure patients. Am J Kidney Dis. 2003;41(5):997-1007.

20. Lafage-Proust MH, Combe C, Barthe N, Aparicio M. Bone mass and dynamic parathyroid function according to bone histology in nondialyzed uremic patients after long-term protein and phosphorus restriction. J Clin Endocrinol Metab. 1999;84(2):512-9.

Sources of funding: None Conflict of interest: None Date of first submission: January 29, 2004 Last received: February 4, 2005 Accepted: February 9, 2005 


\section{AUTHOR INFDRMATIDN}

Carlos Perez Gomes, MD. Nephrology Division, Hospital Universitário Pedro Ernesto, Universidade do Estado do Rio de Janeiro, Rio de Janeiro, Brazil.

Maria Inês Barreto Silva. Nutritionist, Hospital Universitário Pedro Ernesto, Universidade do Estado do Rio de Janeiro, Rio de Janeiro, Brazil.

Maria Eugênia Leite Duarte, MD. Histology and Embryology Department, Faculdade de Medicina, Universidade Federal do Rio de Janeiro, Rio de Janeiro, Brazil.

David Dorigo. Statistician, Hospital Universitário Pedro Ernesto, Universidade do Estado do do Rio de Janeiro, Rio de Janeiro, Brazil.

Carla Cavalheiro da Silva Lemos. Biologist; Hospital Universitário Pedro Ernesto, Universidade do Estado do Rio de Janeiro, Rio de Janeiro, Brazil.

Rachel Bregman, MD. Nephrology Division, Hospital Universitário Pedro Ernesto, Universidade do Estado do Rio de Janeiro, Rio de Janeiro, Brazil.

Address for correspondence:

Rachel Bregman

Rua Soares Cabral, 71 - Apto. 401 - Laranjeiras

Rio de Janeiro (R) - Brasil - CEP 22240-070

Tel. (+55 21) 2551-8548 - Fax. (+55 21) 2587-6227

E-mail: bregmanr@terra.com.br

\section{Comprometimento ósseo de pacientes portadores de doença renal crônica em tratamento conservador}

CONTEXTO E OBJETIVO: A doença óssea em pacientes com doença renal crônica sob tratamento conservador tem sido pouco estudada. O objetivo do estudo foi avaliar a doença óssea em pacientes com doença renal crônica.

TIPO DE ESTUDO E LOCAL: Estudo de casos, na Disciplina de Nefrologia, Hospital Universitário Pedro Ernesto.

MÉTODOS: Foram avaliados por pelo menos um ano 131 pacientes com clearance de creatinina variando de 10 a $60 \mathrm{ml} / \mathrm{min} / 1,73 \mathrm{~m}^{2}$. No plasma, foram medidos creatinina, albumina, cálcio, fósforo, fosfatase alcalina, $\mathrm{CO}_{2}$ total $\left(\mathrm{t} \mathrm{CO}_{2}\right)$, hormônio paratiroidiano intacto (iPTH) e fosfatase alcalina. Da urina de 24 horas, foram avaliadas o clearance de creatinina e a ingestão protéica.

RESULTADOS: Pacientes com clearance de creatinina $<30 \mathrm{ml} / \mathrm{min} / 1,73 \mathrm{~m}^{2}$ apresentaram maior nível de iPTH, apesar de valores normais para.cálcio, fósforo, fosfatase alcalina e $\mathrm{CCO}_{2}$. Pacientes com valores de iPTH duas vezes acima do valor superior da normalidade $(144 \mathrm{pg} / \mathrm{ml})$ apresentaram menor valor de $\mathrm{CCO}_{2}$ Fosfatase alcalina óssea foi avaliada em 37 pacientes com clearance de creatinina $<30 \mathrm{ml} / \mathrm{min} / 1,73 \mathrm{~m}^{2}$, mostrando correlação com a fosfatase alcalina, mas não com o iPTH. Biópsia óssea em nove pacientes com clearance de creatinina $<30 \mathrm{ml} / \mathrm{min} / 1,73 \mathrm{~m}^{2}$ e iPTH $>144 \mathrm{pg} / \mathrm{ml}$ mostrou osteíte fibrosa (4), lesão mínima (4) e alto remodelamento (1).

CONCLUSÃO: Os resultados apontam para a importância de um controle precoce do iPTH e da acidose metabólica em pacientes sob tratamento conservador para doença renal crônica, no intuito de prevenir as complicações relacionadas com a doença óssea.

PALAVRAS-CHAVE: Osteodistrofia renal. Nefropatias. Insuficiência renal crônica. Hemodiálise. Reabsorção óssea. 